\title{
Seismic stratigraphy of the Klints Bank east of Gotland (Baltic Sea): a giant drumlin sealing thermogenic hydrocarbons
}

\author{
Wiebke Schäfer ${ }^{1}$ (D) $\cdot$ Christian Hübscher $^{1}$ (D) $\cdot$ Daniel Sopher $^{2}$ (D) \\ Received: 12 June 2020 / Accepted: 21 December 2020 / Published online: 12 January 2021 \\ (C) The Author(s) 2021
}

\begin{abstract}
This work analyses six high-resolution multi-channel seismic profiles across the Klints Bank east of Gotland. The Klints Bank consists of a drop-shaped increase of the Quaternary thickness and is oriented in an approximately north-southern direction with a length of over $50 \mathrm{~km}$, a width of about $15 \mathrm{~km}$ and a maximum thickness of $150 \mathrm{~m}$. The glacial origin of the Klints Bank can be verified with the dataset presented in this study. We classify the feature as a (giant) drumlin due to its steep up-ice and tapered down-ice face in combination with an orientation parallel to the ice-flow direction of the Weichselian glaciation. The seismic image of the internal structure of the Quaternary unit shows no uniform stratification or deformation patterns; instead, local subparallel reflection patterns interlayered with transparent units are observed. The averaged seismic velocity of this unit is about $2000 \mathrm{~m} / \mathrm{s}$, which is interpreted as an autochthonous deposition of glaciogenic sediments. Signs of overprinting are interpreted based on the geometry of the flanks of the structure, which appear mostly in the form of collapse structures and lifted blocks due to compressional thrust faulting. Phase-reversed events within and beneath the Quaternary are perceived as strong evidence of fluid (hydrocarbon) presence within the Klints Bank. Organically enriched Palaeozoic shales in south-easterly direction of the Klints Bank presumably give the origin of these thermogenic hydrocarbons.
\end{abstract}

Keywords Seismic stratigraphy · Drumlin formation · Gotland · Hydrocarbon indicators · Glaciogenic sediments · Quaternary evolution · Baltic Basin

\section{Introduction}

Moving glaciers affect the underlying landscape in a number of ways, predominated by erosional processes on the one hand and deposition of glaciogenic material on the other. There is a variety of glacial landforms resulting from these processes (e.g. moraines, drumlins, eskers, mega-scale glacial lineations and meltwater-channels), which provide useful information

Wiebke Schäfer

wiebke.schaefer@studium.uni-hamburg.de

Christian Hübscher

christian.huebscher@uni-hamburg.de

Daniel Sopher

daniel.sopher@sgu.se

1 Institute of Geophysics, University of Hamburg, Bundesstraße 55, 20146 Hamburg, Germany

2 Geological Survey of Sweden (SGU), Box 670, 75128 Uppsala, Sweden about the extent of former ice sheets, their flow direction and dynamics. Submarine glacial landforms, in particular, represent a valuable archive of paleo-glacial processes, as they are less prone to erosion and reworking than subaerial landforms and therefore often better preserved in the geological record (Dowdeswell et al. 2016).

One of the typical landforms occurring in former glacier bed areas are called drumlins, defined by Stokes et al. (2011) as a streamlined oval-shaped hill with a generally steeper upice than down-ice face and the longitudinal axis orientated parallel to the ice flow. The formation process of these features is still a point of controversy and is actively discussed (e.g. Smalley and Unwin 1968; Menzies 1979; Fowler 2009; Fowler 2011; Clark 2010; Hooke and Medford 2013; Menzies et al. 2016). This is largely due to the huge variety of forms and compositions, as well as the lack of information about the internal architecture of investigated drumlins. Former studies mostly rely on geomorphological mapping, borehole data and sampling of drumlin material (e.g. Jørgensen and Piotrowski 2003; Rattas and Piotrowski 2003; Clark et al. 2009; Spagnolo et al. 2011; Stokes et al. 2011; Jakobsson et al. 2016; Menzies 
et al. 2016). High-resolution seismic imagery is very rarely available, and hence, there are few cases of it being utilised as a tool to image the structure of drumlins (e.g. King et al. 2007; Smith et al. 2007).

In the Baltic Sea area, many glaciogenic deposits, including drumlins, occur due to the Pleistocene glaciations. These features have been studied onshore, e.g. in Estonia (Rattas and Piotrowski 2003), on the Danish island Funen (Jørgensen and Piotrowski 2003) and in Northern Sweden (Hättestrand et al. 2004) as well as offshore. Submarine drumlins and eskers have already been identified, e.g. in the Gulf of Bothnia (Jakobsson et al. 2016; Greenwood et al. 2017), mostly occurring in the marginal areas of former Weichselian glacier tongues as so-called drumlin swarms.

The bathymetric overview map in Fig. 1 reveals several morphologically noticeable features and banks in the area of the Gotland basin. This work investigates the submarine Klints Bank located east of Gotland (Fig. 1) with respect to its evolution in the context of glacial processes. After Sopher et al. (2016), the Klints Bank could possibly be the largest drumlin of the Baltic Sea region. To understand more about the genesis of this drop-shaped morphological high, the position of the Klints Bank is analysed with respect to pre-existing structural imprints in the pre-Quaternary surface and its embedding in the surrounding morphology. The Quaternary unit, which is of an extraordinary high thickness in this area (Gelumbauskaite 1995; Sopher et al. 2016), is analysed by means of high-resolution seismic profiles.

In addition to the glacial history of the Klints Bank, the area could also be of interest in the context of hydrocarbon reservoirs in the Baltic Sea. Flodén et al. (2001) describe the existence of elongated Silurian reefs below the Klints Bank, which are assumed to have generally minor reservoir characteristics, although oil residues have been observed in the Silurian Burgsvik sandstone in the south of Gotland (Sivhed et al. 2004). According to Flodén et al. (2001), there is clear

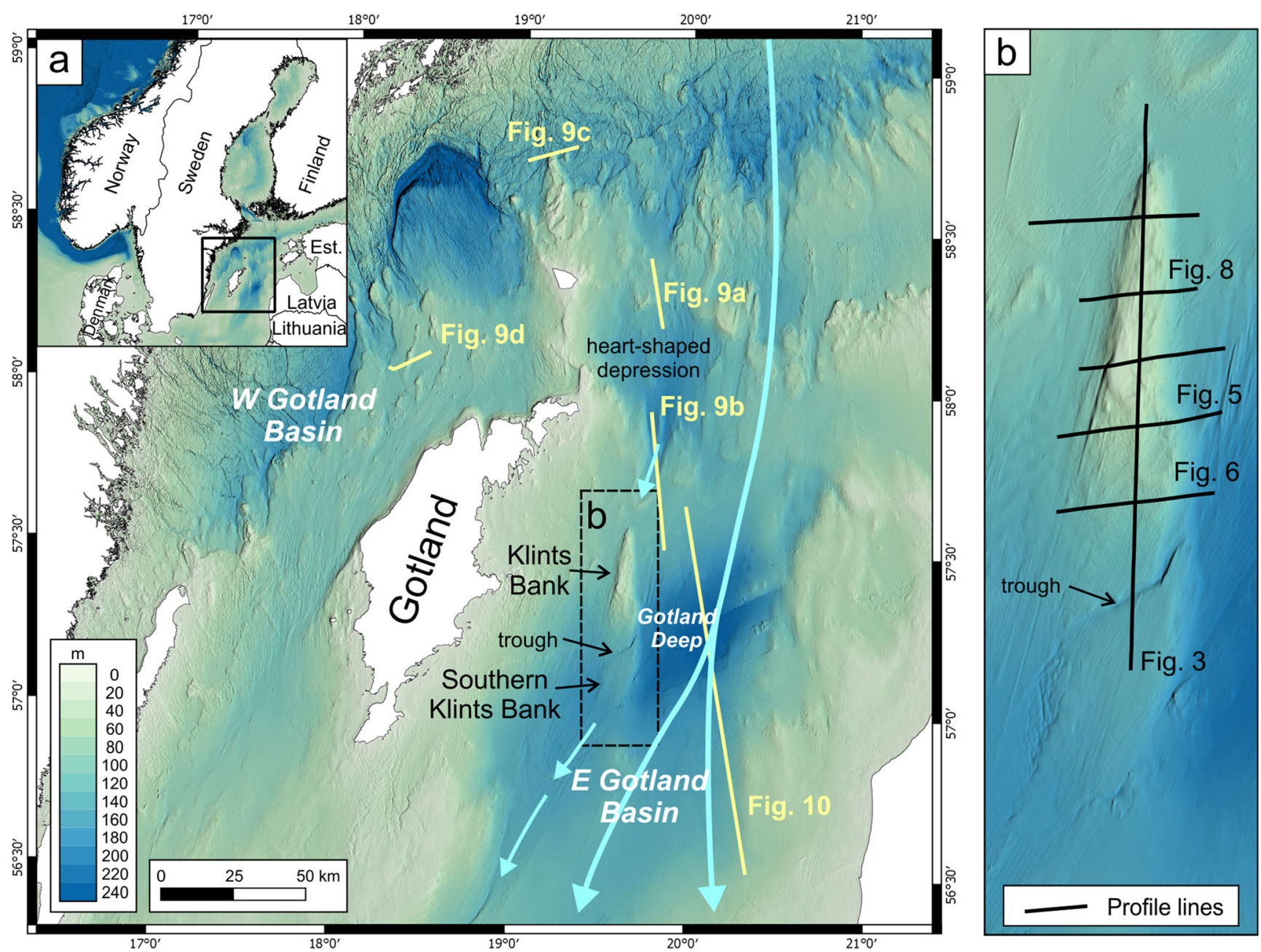

Fig. 1 Bathymetric map of the study area (bathymetric data after EMODnet 2018). a Overview over the Gotland basin with marked geological features. The light blue arrows represent the reconstructed paleo ice-flow direction in the Weichselian glaciation (thick arrows after Woźniak and Czubla 2015, Hall and van Boeckel 2020; thin arrows visualising the refined ice flow we assume around the Klints Bank). b Close-up of the Klints Bank with marked seismic profiles (for the location note the dashed frame marked in map a) 
evidence for hydrocarbon seepages offshore the eastern coast of Gotland, visible as oil stains on the water surface on calm days, but this observation is not definitely constrained.

This leads to the following research questions addressed in the study:

- Is there a pre-Quaternary morphological structure, which caused the formation of the Klints Bank at this specific position?

- Can the classification of the Klints Bank as a drumlin be verified?

- Does the internal structure of the Klints Bank provide indications on the subglacial formation process?

- Does the increased Quaternary thickness play a role as reservoir or seal for hydrocarbons?

The present data acquired onboard RV Alkor offer the rare opportunity to image the internal structure of a potential drumlin seismically, which provides us with useful information about the formation process of glaciogenic landforms at the base of glacial ice sheets.

\section{Geological setting}

\section{Geological evolution}

The seismic profiles investigated in this study are located in the northeast-southwest striking Baltic Basin (Fig. 2), which extends in a north-easterly direction from the Southern Permian Basin (McCann et al. 2008). The evolution of the Baltic sedimentary basin in the western part of the East European Craton began during the late Ediacaran to early Cambrian time and is associated with the break-up of the Rodinia supercontinent (Šliaupa et al. 2006; Šliaupa and Hoth 2011). The most significant period of formation for the Baltic Basin took place during the Caledonian Orogeny (late Silurian/early Devonian) where the basin developed as a flexural foreland basin (Šliaupa 1999; Šliaupa and Hoth 2011). Many structures formed during these periods still outline the present-day morphology in the Baltic Sea region (Gelumbauskaite 1995).

The Quaternary history of the Baltic Basin is dominated by glacial phases in the Pleistocene. As summarised by $\mathrm{Al}$ Hseinat and Hübscher (2017), the study area and adjacent areas have experienced at least three extensive glaciations: the Elsterian, Saalian and Weichselian ice sheets (Ehlers et al. 2011; Hughes et al. 2016; Roskosch et al. 2015). The ice movement direction was approximately perpendicular to the present shoreline of the Baltic Sea Basin (Piotrowski 1997; Piotrowski and Tulaczyk 1999). These glaciations caused strong erosion of the Palaeozoic units especially in the western part of the basin. The end of the latest glacial period - the
Weichselian glacial - about 10,000 years ago initiated the development of the present-day Baltic Sea (Andrén et al. 2011). Today, it is clear that the present-day form of the Baltic Sea is a combination of the pre-existing Palaeozoic basin structures overprinted with the effects of glacial erosion (Šliaupa and Hoth 2011).

The formation of the present Eastern Gotland Basin including the Gotland Deep in the central Baltic Sea east of Gotland (Fig. 1) is considered to be the result of the interaction of tectonic and eustatic processes as well as denudation and glacioisostasy in context of the latest glacial periods. Furthermore, it is closely linked to the evolution of the Baltic Shield (Gelumbauskaite 1995). After Gelumbauskaite (1995), the "Gotland Depression" (Eastern Gotland Basin) is divided into a western and eastern basin by two swells, which are called the Klints Bank (northern swell) and the Southern Klints Bank (southern swell). The Klints Bank is located at the western margin of the Gotland Deep, where water depths reach up to $250 \mathrm{~m}$, the greatest depths in the entire Eastern Gotland Basin (Fig. 1). In Sviridov and Emelyanov (2000), the Klints Bank is described as one of many moraines, which are typically characterized by seismic velocities of 1500 to $2200 \mathrm{~m} / \mathrm{s}$ and densities between 1.8 and $2.4 \mathrm{~g} / \mathrm{cm}^{3}$. By means of industrial seismic profiles the structure is identified as a glacial formation (Sopher et al. 2016), which possibly represents the largest drumlin in the offshore Baltic Sea. It is characterized by a locally increased Quaternary thickness and is based on the eroded surface of the Palaeozoic bedrock. After Sopher et al. (2016), the Silurian units around the Klints Bank have seismic velocities in the range of 3200 to $5000 \mathrm{~m} / \mathrm{s}$, determined by analysis of well measurements in nearby boreholes, such as BO-12 (Fig. 2).

Figure 2 shows the stratigraphic interpretation of an industrial seismic line after Sopher et al. (2016) with its location marked in the profile map in the bottom right corner. The stratigraphy is correlated with the borehole in position $\mathrm{E}$ (BO12) and illustrates clearly the local increase of the Quaternary thickness associated with the Klints Bank. The underlying Palaeozoic units are bedded concordantly on top of the Precambrian bedrock and dip in a south-easterly direction into the Baltic Basin. This is especially visible in the south-north striking parts of the profile (shown between sections A-C, D-E and F-G). Devonian strata represent the youngest Palaeozoic strata along the profile and are only present in the southern part. Hence, the Pre-Quaternary bedrock in the Eastern Gotland Basin consists primarily of Palaeozoic units as depicted in the profile map (Fig. 2 bottom right). The age of the bedrock decreases from Precambrian age at the Swedish coast in the northwest of the map, to Silurian age around Gotland, to Mesozoic age further to the southeast. The depth of this Pre-Quaternary surface near Gotland does not reveal any form of morphological high in the area of the Klints Bank, but dips into the Gotland Deep east of Gotland (Šliaupa et al. 1995). 


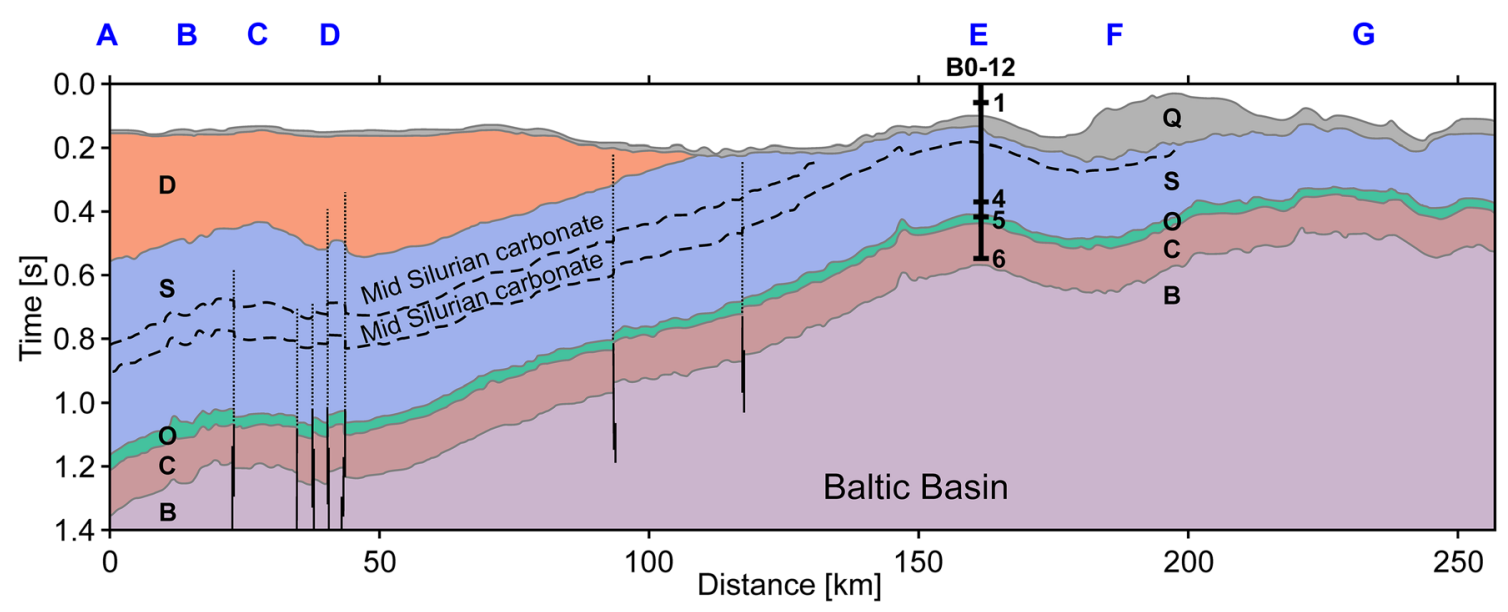

Seismic Interpretation

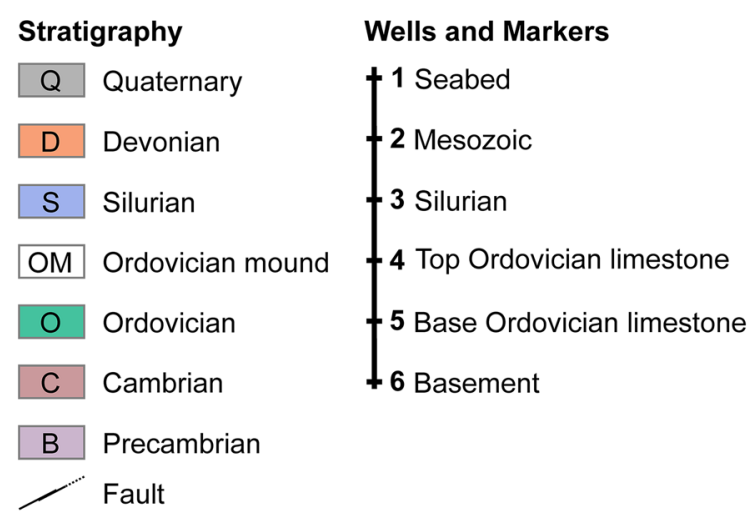

Marine Bedrock Geology Map

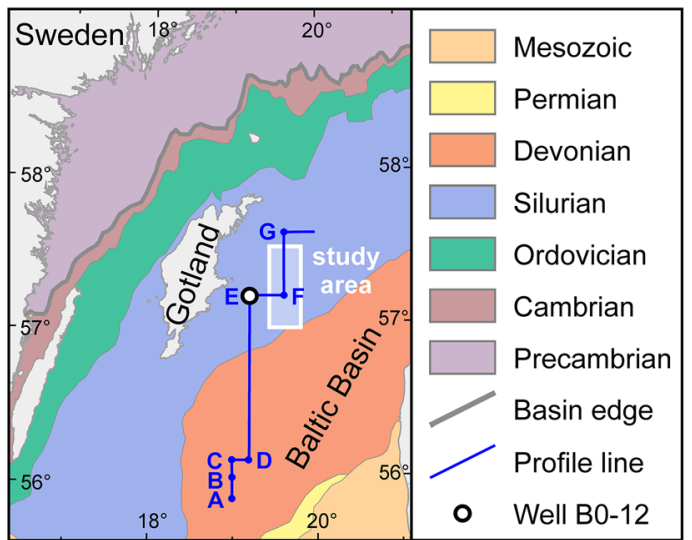

Fig. 2 Stratigraphic interpretation of a seismic profile (section) crossing the Eastern Gotland Basin. The profile map (bottom right) indicates the marine bedrock geology of the region as well as the locations of the borehole BO-12 and the study area (modified from Sopher et al. 2016)

\section{Hydrocarbon reservoirs}

The Baltic Basin is a proven region for hydrocarbons, where more than 700 deep wells have been drilled and over 40 hydrocarbon accumulations have already been discovered (Brangulis et al. 1993; Freimanis et al. 1993; Kanev et al. 1994; Dobrova et al. 2003; Zdanaviciute and Lazauskiene 2004; Šliaupa et al. 2004; Šliaupa and Hoth 2011), of which some are commercial. These reservoirs consist mainly of Middle Cambrian sandstones, which are underlain by organic rich Middle Cambrian shales and are sealed upwards by shales of Ordovician to Silurian age (De Vos et al. 2010; Pletsch et al. 2010). Ordovician carbonates in the Baltic Sea provide a secondary, less volumetrically significant reservoir in the Baltic region (De Vos et al. 2010). The production of oil from Ordovician carbonate mounds has been significant on Gotland and first began in the 1940s (Johansson et al. 1943). Furthermore, Flodén et al. (2001) describe clear indications of hydrocarbon seepages in the Silurian reef area, east of Gotland. However, in other studies, there is no verification for the accumulation of hydrocarbons in these Silurian reefal structures (Šliaupa and Hoth 2011). Furthermore, the black graptolitic shales of the Upper Ordovician and Silurian are in principal thermally mature enough to generate hydrocarbons (De Vos et al. 2010) and therefore considered potential source rocks.

Zdanaviciute and Lazauskiene (2004) compiled oil discoveries in Silurian reefs and Cambrian reservoirs along or near the Baltic coasts of Russia, Lithuania and Latvia. Geochemical data indicate the presence of mature Silurian source rocks onshore western Lithuania (Zdanaviciute and Lazauskiene 2007). Wagner (2011) mapped a zone of increased hydrocarbon concentration both in bottom sediments and in bottom water. These authors attributed the main migration routes of liquid and gaseous hydrocarbons originating from subsurface geological structures to major fault zones and related systems of fissures. However, they also found evidences for migration of subsurface hydrocarbons through the pinch-out zones of sedimentary complexes.

\section{Glacial landforms in the Baltic Sea area}

In today's Baltic Sea and adjacent land areas, several glacial landforms provide evidence of paleo ice movement during the 
Pleistocene glaciations (e.g. Hättestrand 1998; Hättestrand et al. 2004; Greenwood et al. 2016). Drumlins have already been identified, e.g. in Estonia (Rattas and Piotrowski 2003), Latvia (Saks et al. 2012), Finland (Heikkinen and Tikkanen 1989) and the Gulf of Bothnia (Jakobsson et al. 2016; Greenwood et al. 2017), where they often form so-called drumlin swarms in the marginal areas of former Pleistocene glacier tongues. Jakobsson et al. (2016) present a submarine drumlin swarm in the southern Gulf of Bothnia, which is further analysed in Greenwood et al.'s (2017) study. The drumlins in this area often have a bedrock core, which is also observed onshore in Northern Sweden (Hättestrand 1998; Hättestrand et al. 2004) and on the Danish island Bornholm (Jakobsen 2012). Rattas and Piotrowski (2003) describe the Estonian Saadjärve drumlin field and connect the size and form of the individual drumlins to the permeability of the underlying bedrock, which influences the drainage of meltwater at the ice base and therefore the coupling of ice and bedrock. The drumlins in this field reach a maximum of $12 \mathrm{~km}$ in length, $60 \mathrm{~m}$ in height, and $24 \mathrm{~km}^{2}$ in surface area. Similarly, the influence of the bedrock characteristics on the formation of drumlins is described in Saks et al. (2012) for a drumlin field in Latvia, but here, the pore fluid pressure at the ice base is taken into account additionally. Within this drumlin field, there are 21 drumlins in total, whose individual lengths vary between 1.5 and $5 \mathrm{~km}$.

\section{Data and methods}

The analysed dataset over the Klints Bank consists of six highresolution multi-channel seismic profiles acquired by the University of Hamburg (Germany) in cooperation with the University of Uppsala (Sweden) in 2017 onboard RV Alkor (cruise AL502). The seismic lines of about $136 \mathrm{~km}$ in total cover the Klints Bank in a north-south as well as a west-east direction, as depicted in Fig. 1. Two GI-Guns operated in "true GI mode" (each one with an air volume of $45 \mathrm{in}^{3}$ for the generator and $105 \mathrm{in}^{3}$ for the injector) were fired every $10 \mathrm{~s}$, resulting in a nominal shot interval of $25.72 \mathrm{~m}$. The recording system consisted of a 144-channel digital streamer with an active length of $600 \mathrm{~m}$ that was towed at a depth of about $4 \mathrm{~m}$ below sea surface. Furthermore, seismic sections of the surrounding area are shown, which were acquired on RV Alkor as well. The data instances in Fig. 9a-c have been acquired during student educational cruises by the University of Hamburg. The profiles presented in Fig. 9 were acquired in 2017 during the abovementioned cruise AL502 (Fig. 9d). The seismic section shown in Fig. 10 has been recorded during RV Alkor cruise AL526 in 2019 (Hübscher et al. 2020). The seismic source was a mini-GI; each of the volumes was $15 \mathrm{in}^{3}$. A 48-channel analogue streamer of 200$\mathrm{m}$ active length received the data. Further information about the seismic method can be found, e.g. in Hübscher and Gohl (2016). The data processing was performed using the VISTA ${ }^{\circledR}$ Seismic Data Processing Software by Schlumberger. Significant processing steps include filtering, deconvolution in $\tau$-p-domain, velocity analysis, stacking and migration. These steps where applied to remove noise and multiples as well as to resolve the internal structures of the Quaternary unit.

\section{Results}

The description of results is based on data examples and mainly focuses on the shape and location of the Klints Bank, internal reflection patterns visible in the seismic profiles and phase reversals, but also shows additional seismic profiles of the surrounding area. Stratigraphic assignments follow the borehole information of the nearby borehole BO-12 published in Sopher et al. (2016). For its location, see Fig. 2 (position E).

\section{Seafloor and bedrock topography}

In the bathymetric map of the study area (Fig. 1), the Klints Bank appears as an elongated morphological high at the northwestern edge of the Gotland Deep. Its dimensions are approximately $50 \mathrm{~km}$ in length and $15 \mathrm{~km}$ in width, and it builds up a bathymetric high separating the Eastern Gotland Basin (Fig. 1) into a western and an eastern part (including the Gotland Deep). A small northeast-southwest trending trough (Fig. 1) separates the Klints Bank from the Southern Klints Bank. To the north of the bank, the bathymetry is characterised by a heart-shaped depression pointing towards the Klints Bank.

The longitudinal axis of the elongated bathymetric high has an azimuth of approximately $10^{\circ}$ (southwest-northeast), which is fairly well-aligned with the reconstructed general ice-flow direction marked in Fig. 1 (Woźniak and Czubla 2015; Patton et al. 2016; Hall and van Boeckel 2020). Figure 3 shows the north-south striking profile passing the formation in longitudinal direction (note the vertical exaggeration of about VE=54). The northern face of the Klints Bank is characterised by a steeply rising seafloor, due to an abrupt increase in the thickness of the Quaternary section. In the segment from 10 to $20 \mathrm{~km}$ distance, the seafloor stays approximately horizontal, before it tapers down along the southern flank of the bank. In the southern part of the profile the channel structure outlined above appears as a pronounced incision of about $3 \mathrm{~km}$ width into the Quaternary unit. The surface of the Quaternary unit shows a rough hummocky structure, which is particularly apparent at the base of the northern flank and on the southern flank.

The acoustic basement of the Quaternary Klints Bank (in the following called "Base Quaternary"; BQ) is marked by a strong reflection in all profiles and is equivalent to the top of 


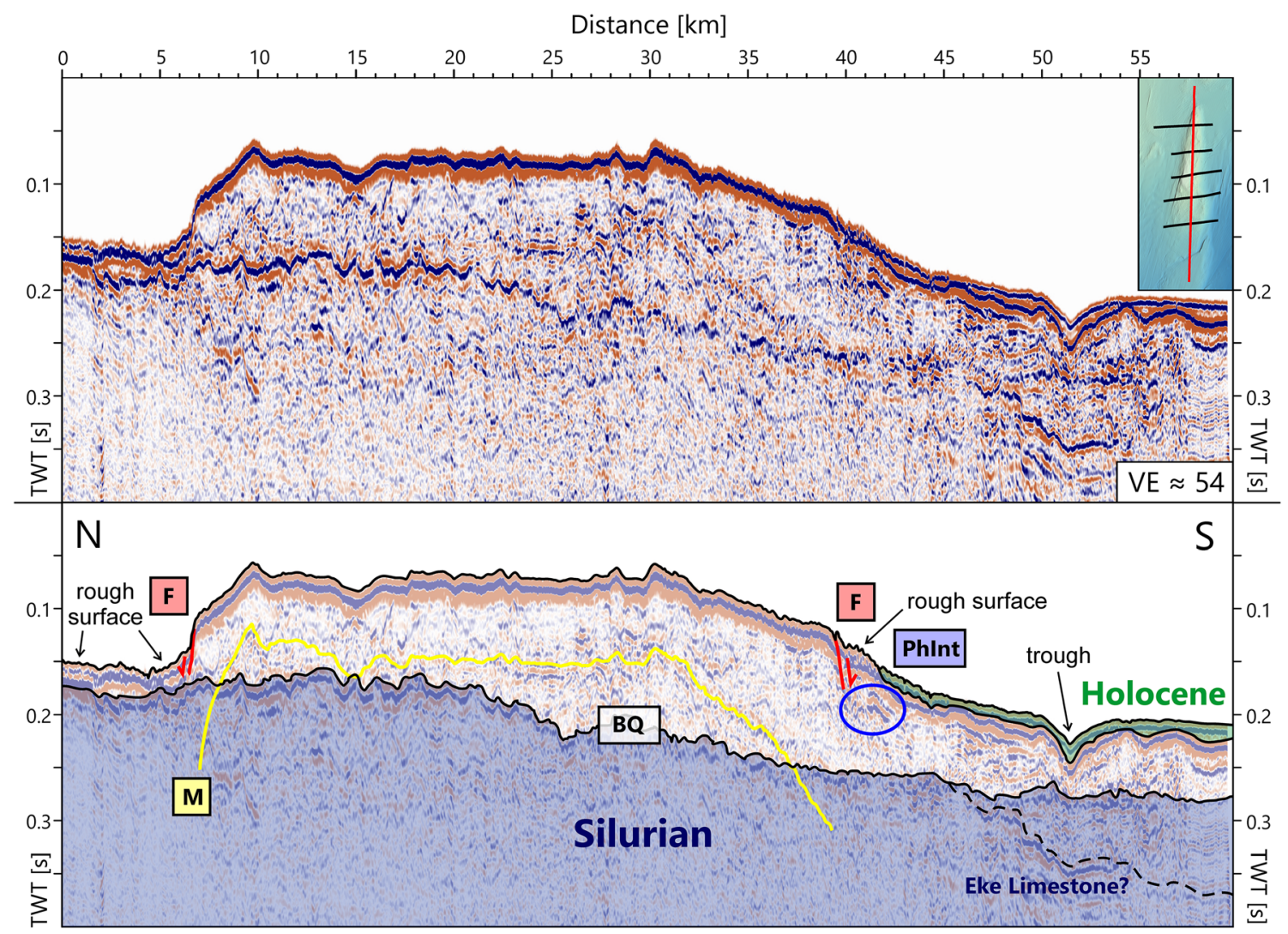

Fig. 3 Stacked section and stratigraphic interpretation of the north-south striking profile (see map). The following abbreviations are used: "BQ" base Quaternary, "F" - disturbed/faulted flank $(\rightleftharpoons$ indicates direction of

the Silurian in most areas. In the southern part of the northsouth profile (Fig. 3), there is an additional strong reflection visible, which dips down to about 0.37 -s travel time at the southern end of the profile. The stratigraphic assignment of this horizon (marked with a dashed line) is not constrained by the borehole data and discussed later. In the following, the upper horizon at about 0.27 -s travel time is considered part of the BQ.

Figure 4a shows an interpolation of the BQ for all profiles in the time domain (seismic two-way-time (TWT)). For better orientation, the outline of the morphological high is marked with a dashed line (Fig. 4a-c). Due to the irregular distribution of data points along and between the profiles, the interpolation was performed using a cell size of $0.5 \mathrm{~km}$ to minimise interpolation artefacts. The interpolated surface generally dips to the southeast and shows an elongated convex upwards form parallel to the longitudinal axis in the northern part of the Klints Bank. A simple depth conversion, with assumed (constant) interval velocities of $v_{\text {Water }}=1500 \mathrm{~m} / \mathrm{s}$ for the water column, $v_{\text {Holocene }}=1700 \mathrm{~m} / \mathrm{s}$ for the Holocene deposits and $v_{\text {Quaternary }}=2000 \mathrm{~m} / \mathrm{s}$ for the Quaternary unit leads to a depth reconstruction of the underlying surface shown in Fig. 4b. The interpolated surface in the depth domain is also dipping towards the southeast but does not show any morphological high along the drumlin axis. movement), "PhInt" - internal phase reversal (within the Quaternary unit), "M" - seafloor multiple

Figure $4 \mathrm{c}$ presents the thickness of the Klints Bank, derived by the depth conversion of the travel time difference between the interpolated BQ and the interpolated Quaternary surface. To calculate the thickness map, an average seismic velocity of $v_{\text {Quaternary }}=2000 \mathrm{~m} / \mathrm{s}$ within the Klints Bank was assumed. Hence, the values of the travel time difference in milliseconds directly correspond to the estimated Klints Bank thickness in metres. The figure shows the oval-shaped increase of the Klints Bank thickness, which rises steeply from $10 \mathrm{~m}$ at the northern end of the study area, reaches its maximum of about $150 \mathrm{~m}$ in the centre and then decreases slightly to a thickness of $60 \mathrm{~m}$ at the southern end of the area. Furthermore, the width of the formation increases southwards.

\section{Internal reflection patterns}

Figure 5 shows one of the west-east trending profiles used as an example for the description of the predominant reflection patterns. The internal reflection configuration within the Quaternary unit comprises sub-parallel to irregular patches of reflections, which are interlayered with transparent or chaotic units. A correlation of particular horizons between different profiles is not possible due to the distance between the 


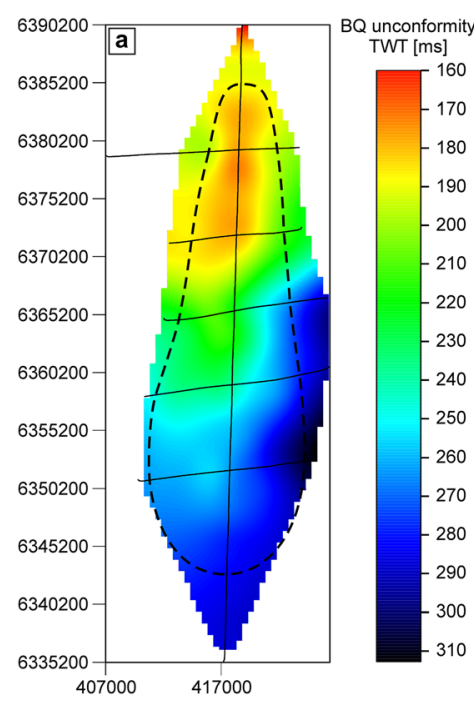

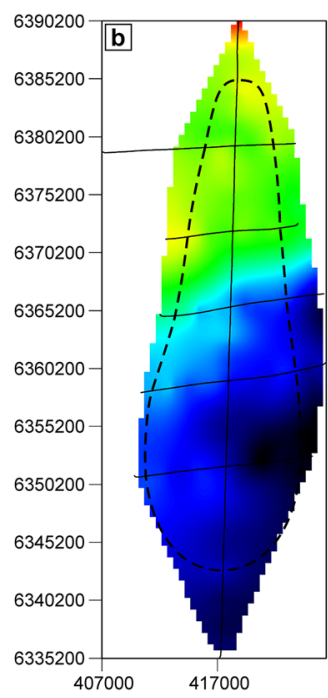

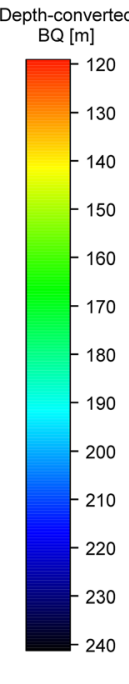

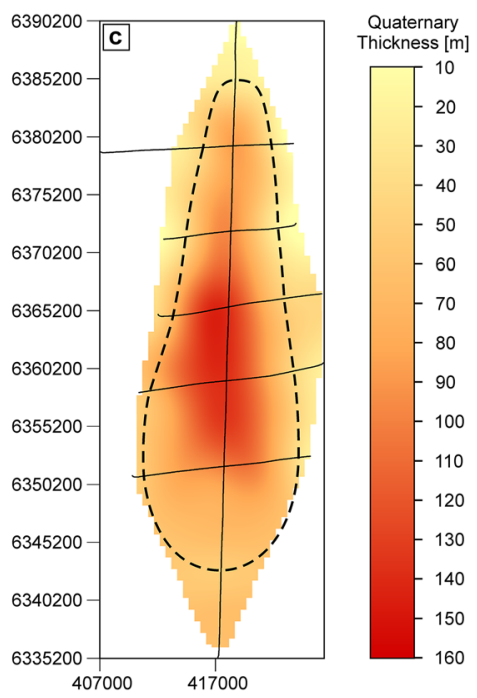

Fig. 4 Colour-coded grids with a cell size of $0.5 \mathrm{~km}$ (Klints Bank outline marked with a dashed line). a Interpolation of the Base Quaternary (BQ) unconformity in the time domain. $\mathbf{b}$ Interpolated BQ in the depth domain (depth below mean sea level in metres), this can be considered to be a reconstruction of the surface below the bank. $\mathbf{c}$ Klints Bank thickness estimated by depth conversion of the travel time difference between the $\mathrm{BQ}$ and Quaternary surface (all calculations assuming $v_{\text {Water }}=1500 \mathrm{~m} / \mathrm{s}$ and $v_{\text {Quaternary }}=2000 \mathrm{~m} / \mathrm{s}$ )

rough structures of the hummocky glacial surface. The internal reflections in this profile (Fig. 5) are mainly unsorted and therefore reflect the predominantly chaotic pattern. The amplitudes vary in a wide range with distinct high- $\left(\mathrm{A}^{+}\right)$and low$\left(\mathrm{A}^{-}\right)$amplitude patches highlighted in the figure. Another recurrent feature is visible on the western side of the structure; this area is characterized by a steep flank and a highly irregular
Fig. 5 Stacked section and stratigraphic interpretation of a west-east striking profile (see profile map). The following abbreviations are used: "BQ" base Quaternary, "A" - amplitude anomaly (+ high amplitude, - low amplitude), "F" - disturbed/ faulted flank $(\rightleftharpoons$ indicates direction of movement), "M" seafloor multiple

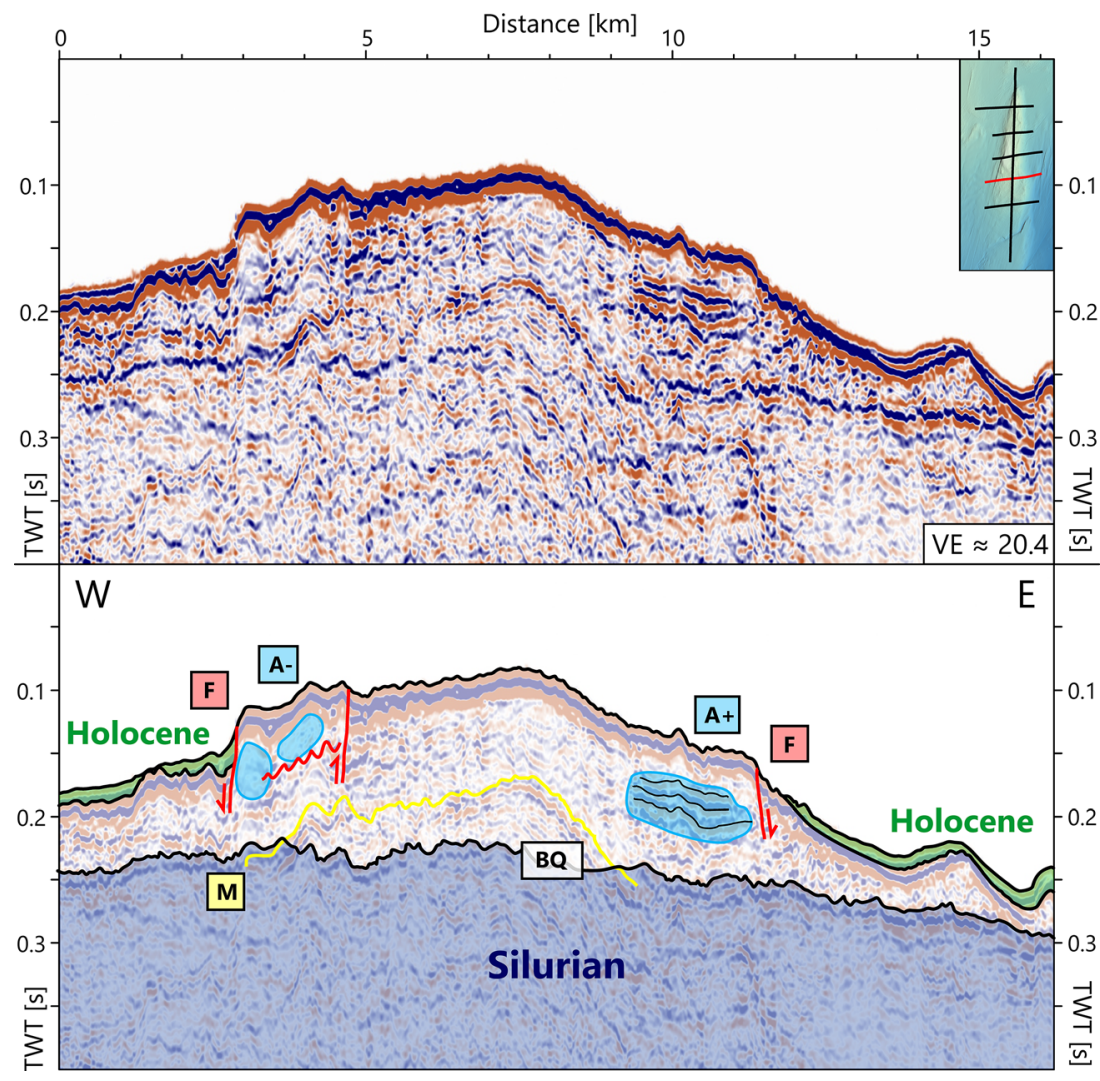


surface of the glacial deposits. A similar, but less obvious disruption pattern can be found on the eastern flank of this profile, as well as on most of the other profiles. Disturbed or faulted areas such as this are marked with the abbreviation "F" in the seismic sections. In Fig. 5, the fault at the western flank marks the western boundary of a block, which is confined by two faults and exhibits increased thickness of the Quaternary unit. A similar configuration occurs in Fig. 8 at the eastern flank of the Klints Bank. Both blocks show a hummocky structure, which can be seen not only at the surface of the Quaternary but also on an internal reflection in Fig. 5.

\section{Phase reversals}

Phase reversals do not only occur in the case of multiple reflections but also at the base and within the Quaternary unit. While the seafloor shows the normal colour sequence "orange - blue - orange" the reversed polarisation is characterised by the reversed colour sequence "blue - orange - blue". An obvious example for an internal phase-reversed reflection (abbr. "PhInt") can be found in Fig. 6 as well as at the intersecting position in the north-south profile (Fig. 3) and occurs between 20 and $40 \mathrm{~ms}$ below the seafloor. It is marked with the abbreviation "PhInt" in both sections. Figure 7 shows the corresponding event in the raw first-channel data after application of a simple Butterworth bandpass filter. Since the phase reversal is still clearly visible and its amplitude is comparable to the seafloor reflection, an artificial generation of the phase reversal throughout the data processing (deconvolution, stacking, etc.) can be ruled out. Other examples for internal phasereversed reflections are visible, e.g. in Fig. 5, at the boundary of the low-amplitude patches.

Figure 8 shows some phase reversals within the BQ (abbr. "PhBas"), which are marked in two close-up frames. The polarisation of the base reflection changes here within small segments from "orange - blue - orange" (normal) to "blue orange - blue" (reversed). As in the case of the internal phasereversed events, the phase reversals in the base reflection can also be identified in the raw data from the first channel (as in Fig. 7). The lateral extent of the phase reversal is difficult to determine due to the overlain seafloor multiple.

\section{Comparative seismic sections}

The bathymetric map in Fig. 1 reveals several morphologically noticeable features and banks in the area of the Gotland Basin. However, the distinction between (glaciogenic) depositional origin and formation as erosional remnant by bathymetric data only is often not trivial and requires insight from seismic sections or borehole samples. In order to evaluate and compare the Klints Bank profiles in the regional context of the Gotland Basin, some other seismic profiles crossing
Fig. 6 Stacked section and stratigraphic interpretation of a west-east striking profile (see profile map). The following abbreviations are used: "BQ" base Quaternary, "A" - amplitude anomaly (+ high amplitude, - low amplitude), "F" - disturbed/ faulted flank $(\rightleftharpoons$ indicates direction of movement), "PhInt" internal phase reversal (within the Quaternary unit)

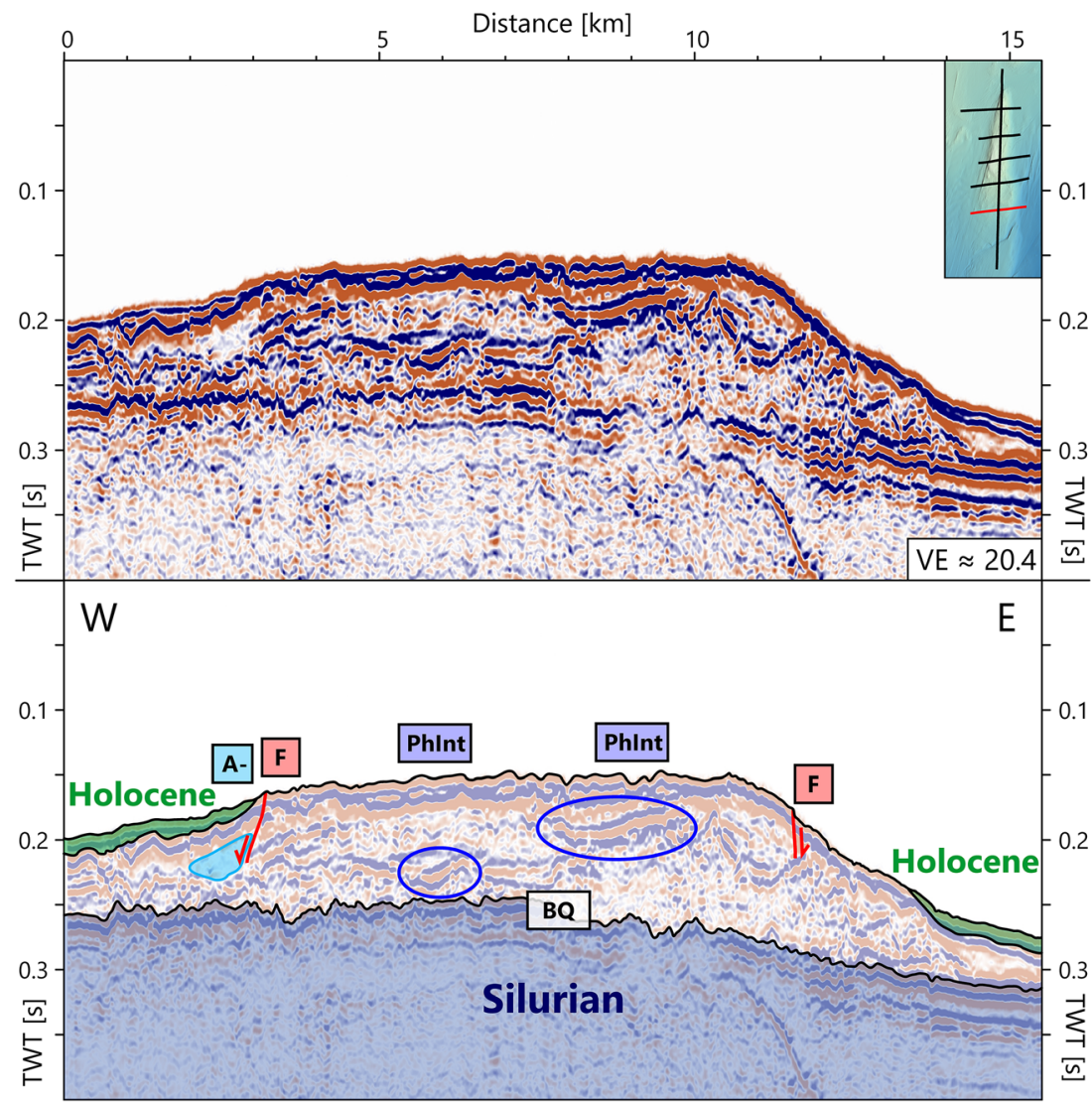




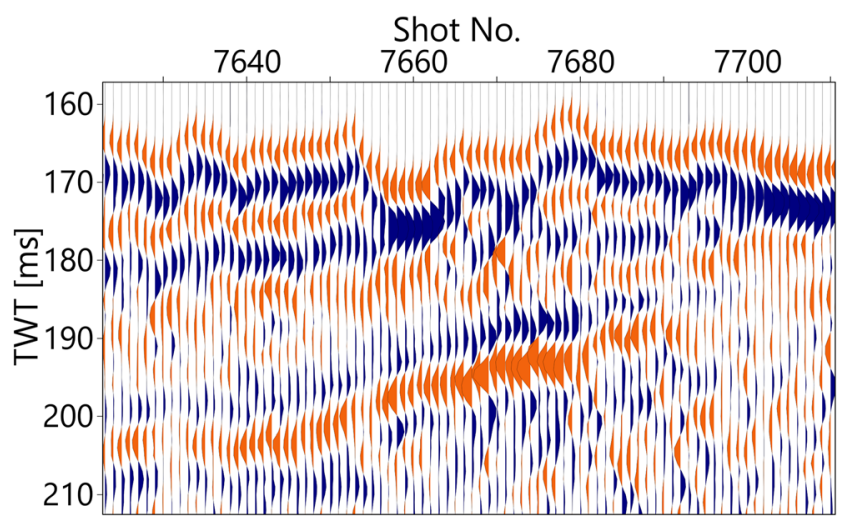

Fig. 7 Section of the profile in Fig. 6 showing one of the internal phasereversed events in the raw bandpass-filtered first-channel data (blue: positive amplitude, orange: negative amplitude) morphologically interesting features are considered (Fig. 9ad). The locations of these profiles are marked in Fig. 1.

Figure 9a and b show two approximately north-southstriking sections north to northeast of the Klints Bank with marked glaciogenic deposits. Figure 9a shows several small hills/ridges consisting of glaciogenic sediments on top of a quite smooth (Ordovician) surface without pre-existing morphological highs. These accumulations are seismically transparent and taper towards their tops. The glaciogenic sediments in Fig. 9b were deposited at the northern flank of an edge in the Silurian basement.

The profiles in Fig. 9c and d cross morphological features, whose appearance in the bathymetric map (Fig. 1) is similar to that of the Klints Bank as they also build up elongated banks orientated in an approximately north-south striking direction. The seismic lines (Fig. 9c and d) indicate that both banks
Fig. 8 Stacked section and stratigraphic interpretation of a west-east striking profile (see profile map). The following abbreviations are used: "BQ" base Quaternary, "F" - disturbed/ faulted flank $(\rightleftharpoons$ indicates direction of movement), "PhBas" - phase reversal at the Quaternary base BQ, "M" - seafloor multiple

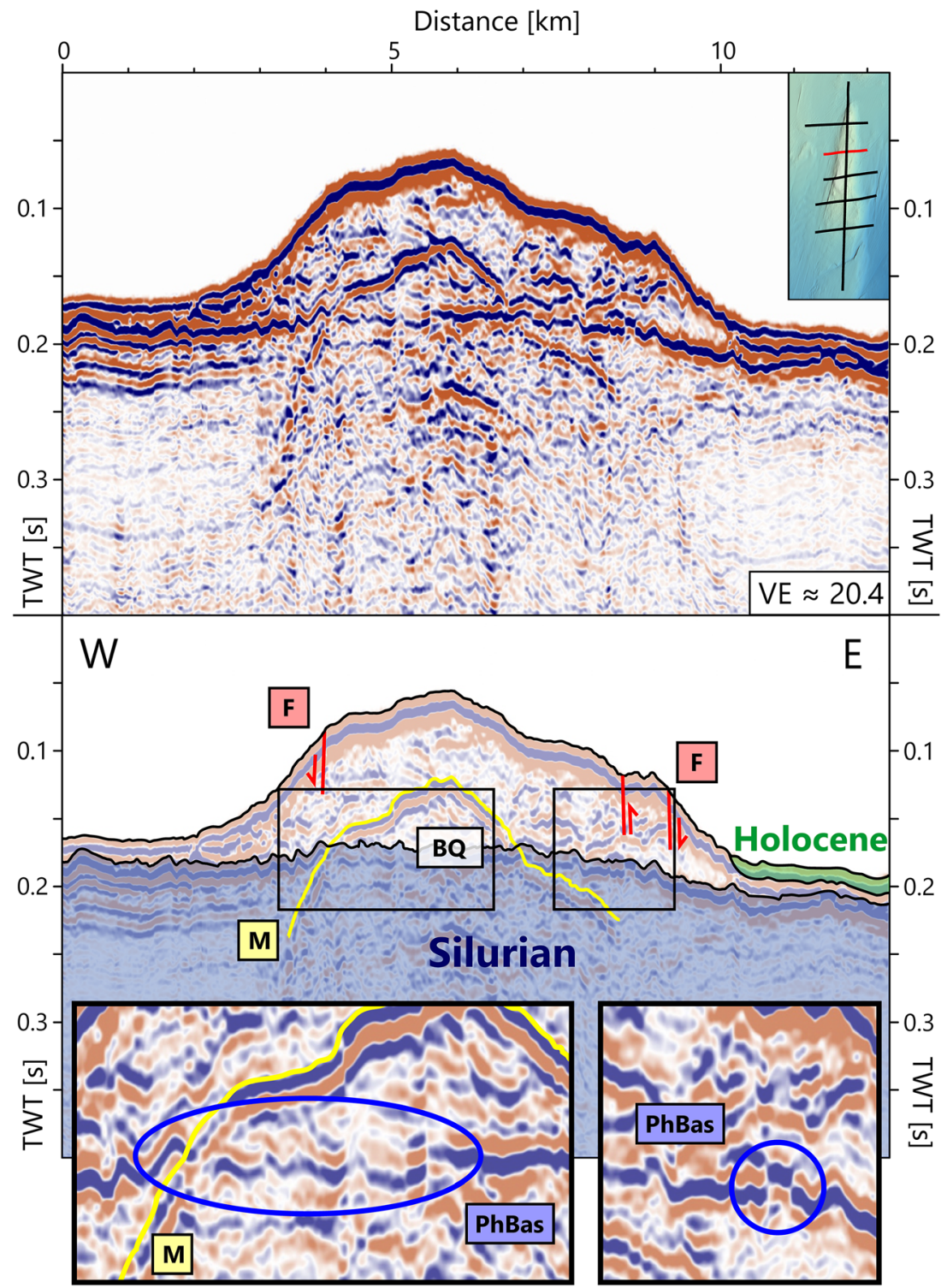


Fig. 9 Comparative seismic sections crossing morphologically noticeable features in the Gotland Basin near the Klints Bank. For location, see Fig. 1. All data are plotted with same scale. a Upwards tapering deposits of seismically transparent glaciogenic sediments. b Glaciogenic deposits accumulated at the northern flank of a step in the Silurian basement c Section across an erosional ridge with very limited signal penetration. d Section across an erosional ridge and adjacent drift body

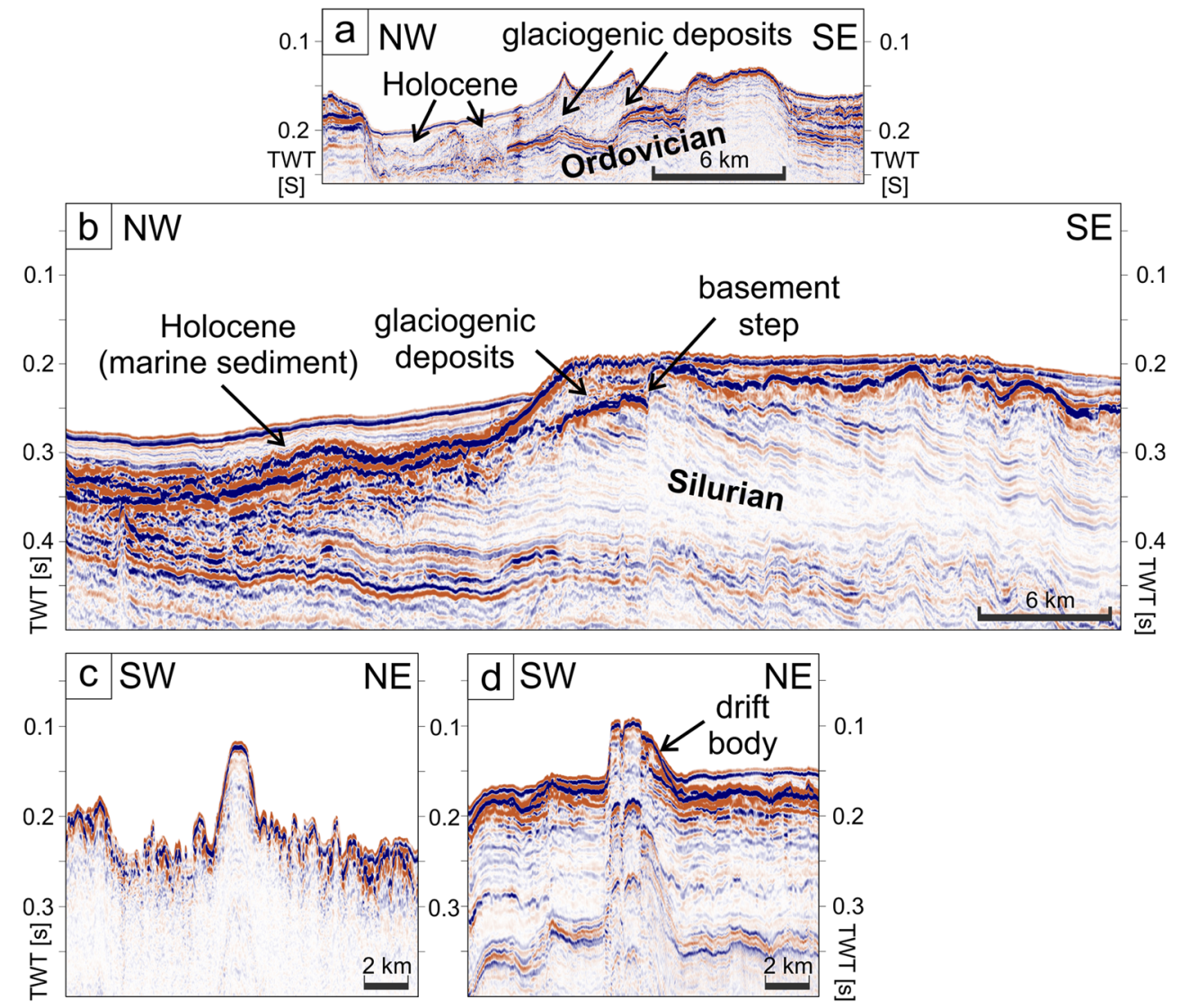

consist of bedrock material and are only thinly covered with glacial or post-glacial deposits. The penetration into the bedrock is quite low, and there are no visible reflections at the base of the features.

In order to set the Silurian bedrock beneath Klints Bank into its geological context and to suggest possible fluid migration paths, a seismic profile pointing from east of the Klints Bank towards the Lithuanian coast in the southeast is presented in Fig. 10. This section crosses the Gotland Deep and shows the Palaeozoic strata (Devonian, Silurian) dipping towards the southeast.

\section{Discussion}

\section{Formation and classification of the Klints Bank}

The question arises why the Klints Bank developed at this particular location. According to Sopher et al. (2016), the Klints Bank rests on Silurian bedrock. The BQ is clearly marked by a continuous and high amplitude reflection along most of the profiles. The additional dipping reflection described at the southern end of the north-south profile (Fig. 3) confines a wedge-shaped unit below the presumed BQ. We interpret this reflection to be the lowermost Mid-Silurian carbonate interpreted in the study by Sopher et al. (2016) (Fig. 2).
This strong reflection is thought to be due to the presence of an approximately 10-m-thick limestone layer within the marldominated Silurian sequence. This unit is interpreted to be equivalent to the Eke Limestone onshore Gotland (Calner et al. 2004).

The upward warping of the BQ in the time domain (Fig. 4a) can be explained by velocity effects due to the increased thickness of the glacial unit. This artefact (known as "velocity pullup"), which effects the base reflection in the time domain is corrected for the depth-converted interpolation in Fig. 4b. The resulting dip of the BQ to the southeast spatially correlates with its position on the northwestern flank of the Gotland Deep. The interpolation is also consistent with the map of the sub-Quaternary surface published in Šliaupa et al.'s study (1995) and interpreted profiles in Sopher et al.'s study (2016). The Klints Bank itself is therefore not built upon a pre-existing bathymetric feature but is located on the upper shoulder of the Gotland Deep. However, the outcrop of limestone at the seabed (the strong reflection interpreted as the Eke Limestone) could potentially lead to different properties (such as friction) at the base of the glacier. Subsequently, this could have been a factor which influenced the accumulation of the material at this position. Other factors that may have affected the position of the bank cannot be determined from the present dataset. The heart-shaped depression in the northeast of the Klints Bank is suggested to play a role in this context, as it could 


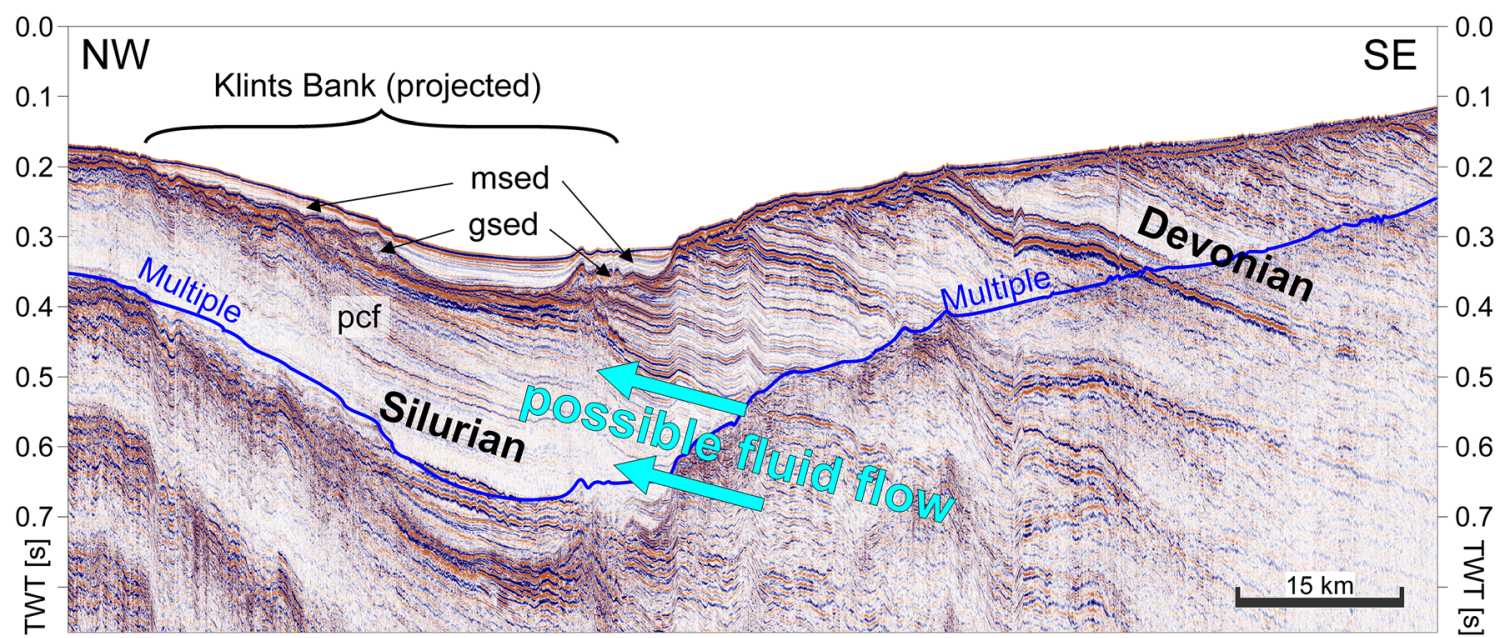

Fig. 10 Seismic section from east of Klints Bank (NW) towards the Lithuanian coast (SE). For location, see Fig. 1. gsed, glaciogenic sediments; msed, marine sediments; pcf, prograding clinoforms

have led to a narrowing of the southward flowing ice masses. The resulting change in the flow velocity at the focused basin outflow or a varying ice-basement-coupling could have induced the local accumulation of glaciogenic sediments below the moving ice.

The Quaternary origin of the Klints Bank suggested by Sopher et al. (2016) can be validated with the present dataset. Generally, the average seismic velocity of about $2000 \mathrm{~m} / \mathrm{s}$ within the Quaternary unit indicates that the Klints Bank consists of glacial till or similar sediments. The purely sedimentary composition rules out the possibility that the Klints Bank is a whaleback feature, which is composed of bedrock. Seismic data across erosional ridges in the vicinity are characterized by the absence of seismic signal penetration into the basement (Fig. $9 \mathrm{c}$ and d). The length-width ratio of Klints Bank is not consistent with the typical appearance of eskers, (mega-scale) glacial lineations or lateral moraines. Lateral or terminal moraines in the vicinity are seismically transparent, which is taken as an indicator for complete internal mixing of glaciogenic sediments (Fig. 9 a and b). Furthermore, the crests of the moraines taper towards their tops. The orientation of Klints Bank parallel to the ice-flow direction is not consistent with interpreting Klints Bank as a terminal moraine. In Sviridov and Emelyanov (2000), the Klints Bank is described as the thickest part of the glacial ground moraine in the Baltic Sea, but not analysed in further detail. The orientation of the long axis parallel to the generally assumed ice-flow direction in combination with the composition of glaciogenic sediments also allows for an interpretation of the Klints Bank as lateral moraine, but the streamlined shape and the symmetric characteristics of the feature make this option implausible.

Its drop-like shape and the orientation parallel to the assumed ice-flow direction in the last glacial period (Weichselian glacial) suggests the classification as a drumlin. Specifically, the steep up-ice flank in the north and the tapering down-ice flank in the south support this hypothesis. Furthermore, the observed internal reflection patches indicate that the Klints Bank comprises at least local internal stratification, which is not the case for the moraines in Fig. 9 a and b. A remobilisation or spatially distributed accumulation over long distances is therefore not likely. An autochthonous sediment accumulation is corroborated and consistent with an interpretation of the Klints Bank as a drumlin. The formation of the Klints Bank as a ground moraine cannot be ruled out with the present dataset, but in terms of the discussed properties, a classification as drumlin is preferred.

In the regional context, considering other drumlins in the Baltic Sea area, the Klints Bank with its dimensions of over $50 \mathrm{~km}$ in length, $15 \mathrm{~km}$ in width and $150 \mathrm{~m}$ in thickness represent an anomalously large glacial feature. In Estonia and Latvia and the Gulf of Bothnia, drumlin fields at the margins of former glacier tongues were discovered, whose single drumlins do not exceed a length of $12 \mathrm{~km}$. The formation of these drumlin fields is assumed to be related to the permeability characteristics of the bedrock (Saks et al. 2012; Rattas and Piotrowski 2003). The Klints Bank differs, therefore, from other drumlins in the Baltic Sea, not only in terms of size but also in the fact that it stands alone, instead of in a field of similar drumlins.

\section{Faults and overprints at the flanks}

The seismic profiles show faults, most notably on the western and eastern flanks, but also on the steep northern flank of the Klints Bank, that can be associated with collapses at the edges of the structure. The notably rough surface of the Quaternary unit at the base of these steep flanks indicates an unsorted deposition of the collapsed flank material. This process seems to have taken place after the initial deposition of the Klints Bank, but still under the influence of glaciation, since the formation of such a rough surface would be atypical for the 
subsequent marine environment. The process that caused the described overprinting cannot be fully determined from this dataset. However, as the described escarpments due to collapses at the flanks of the Klints Bank occur in approximately the same depth (ca. 100-150 ms) all around the structure, we propose that they are associated with deglaciation of the ice sheet. Figure 11 illustrates a possible configuration during deglaciation, where the surface of the Klints Bank was partially melted out of the ice sheet and therefore exposed, while the flanks of the structure remained under the influence of ice load. The remaining ice load on the flanks could explain the formation of faults and flank collapses at the same level.

The blocks of increased thickness, highlighted previously on the western flank in Fig. 5 and on the eastern flank in Fig. 8 , which are bounded by faults on both sides, indicate a compression of the flanks in an uphill direction. This could have caused reverse faulting of these blocks. This hypothesis is supported by the undulated surface of the raised parts and a clearly folded internal reflector in Fig. 5. Both phenomena can be seen as typical indicators of a compressional regime. The relative direction of movement of the blocks is marked with arrows in the interpreted stacked sections (Fig. 5 and Fig. 8). These structures document another post-depositional overprinting of the flanks, which is assumed to be related to the movement of the flowing ice masses. The reverse faults are presumably older than the flank collapses, but this assumption cannot be verified with the present data.

\section{Phase reversals}

Since the phase reversals, observed in Figs. 6 and 8, are clearly visible in the single channel data (Fig. 7), we can rule out that the reversed polarisation represents processing artefacts. Theoretically, the acoustic impedance inversion and negative reflection coefficient may result either from gas charging or from vertical lithology changes.

Regarding the phase reversal at the Klints Bank base, the hypothetic case of vertical lithology changes causing the negative impedance contrast would require glaciogenic strata in the lower Klints Bank with an interval velocity higher than that of the Silurian basement beneath. To examine the plausibility of such a configuration, the range of documented interval velocities of glaciogenic deposits can be taken from other studies. For example, Jørgensen et al. (2003) measured seismic velocities of till, glaciolacustrine clay/silt and meltwater sand and gravel within buried valleys (also called tunnel valleys) by VSP in exploration boreholes onshore Jutland and reported variable velocities between 1750 and $2150 \mathrm{~m} / \mathrm{s}$. Gerok et al. (2017) detected high-velocity infill of presumably glaciolacustrine origin via acoustic logging in a tunnel valley onshore Lithuania, which showed interval velocities of up to $2255 \mathrm{~m} / \mathrm{s}$. In both studies, the high-velocity infill of the tunnel valley created velocity pull-ups in the reflection seismic time sections of some 10 ms TWT. Kristensen and Huuse (2012) used the pull-ups to estimate the seismic velocity of infilling till, which amounted to less than $2200 \mathrm{~m} / \mathrm{s}$ with the exception of one instance $(2370 \mathrm{~m} / \mathrm{s})$. In all these studies, the high interval velocity deposits caused a warping or pull-up of underlying reflection horizons. The interval velocities of glaciogenic deposits measured in the studies mentioned above are well below the velocity of the Silurian strata of ca. $3000 \mathrm{~m} / \mathrm{s}$, according to Bjerkéus and Eriksson (2001) and Tuuling and Flodén (2011). This comparison makes the configuration of vertical lithology changes causing the phase reversal at the Klints Bank base implausible. Furthermore, the spatially limited appearance of phase reversals should be caused by also laterally limited high interval velocity deposits, which should result in a reflection from its top. Such a seismic indicator is not observed in this study. The high interval velocity of the Silurian, the missing top reflection from a high interval velocity deposit and the absence of warped reflections beneath the phase reversals are three observations that are not compatible with the assumptions that the basal phase reversals result from vertical lithological and resulting seismic velocity changes. Instead, the phase reversals at the base of the Klints Bank are a seismic indicator for fluids - most likely hydrocarbons - beneath the Klints Bank, which decrease the interval velocity of the Silurian strata significantly and therefore lead to a negative impedance contrast at the base of the Klints Bank.

The assumption of hydrocarbons is consistent with the general occurrence of reservoir and source rocks in the Baltic Basin (Flodén et al. 2001; Šliaupa and Hoth 2011), but especially by the observation of hydrocarbon leakage on the seafloor (Flodén et al. 2001), or of hydrocarbons within surface
Fig. 11 Illustration of the proposed partial exposition of the Klints Bank during deglaciation. The remaining ice load on the flanks is causing the faults occurring in approximately the same depth at the flanks of the drumlin
$\mathrm{N}$

S
Exposed surface

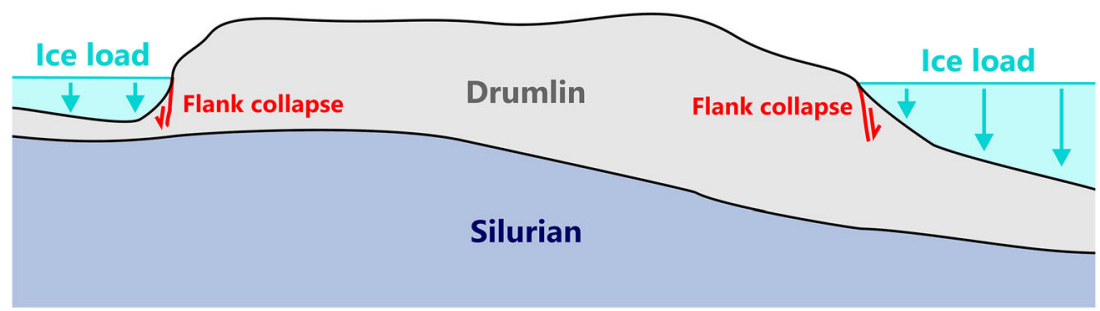


sediments along faults and pinch-out zones (Wagner 2011). Figure 10 shows a seismic profile from east of Klints Bank towards Lithuania, where Zdanaviciute and Lazauskiene (2004, 2007) reported the abundant findings of mature oil. The layers becoming shallower to the northwest represent possible migration paths from the mature oil at the east coast of the Baltic Basin, e.g. along the calcareous Silurian strata or Middle Cambrian sandstones. The Klints Bank represents the stratigraphic seal.

This seal is possibly leaking, because the observation of the internal phase-reversed event identified in Fig. 7 just below the seafloor also indicates the presence of fluids. In principal, these fluids could alternatively originate from organically rich material within the glacial deposits. For example, Laier (2003) explained methane seepage in the Skagerrak-Kattegat area by methane escape from Eemian-Weichselian marine deposits. However, the presence of similar strata has not been reported in our study area. We therefore suggest that the internal phase reversals result from local accumulations of thermogenic hydrocarbons that migrated upwards from the Silurian across the base of the Klints Bank, trapped by impermeable strata.

\section{Conclusions}

In the bathymetry of the Gotland Basin, many morphologically noticeable features are visible. The seismic sections crossing some of these features reveal that the distinction between (glaciogenic) depositional origin and formation as erosional remnant by bathymetric data alone is often not trivial and requires additional insight from seismic sections or borehole samples. The presented seismic sections provide a highresolution image of the Quaternary unit in the area of the Klints Bank, which allows for new conclusions regarding the glacial origin and the internal structure of the Klints Bank as well as its role in the context of fluid occurrence in the Baltic Sea. The morphological high of the Klints Bank is of purely glacial origin and consists of local thickening of the Quaternary unit. It rests on the surface of the Silurian, which dips into the Gotland Deep in a south-easterly direction. The Klints Bank is approximately $50 \mathrm{~km}$ in length, $15 \mathrm{~km}$ in width and reaches a maximum Quaternary thickness of about $150 \mathrm{~m}$. The streamlined drop-like shape of the bank with its steeply dipping northern (up-ice) flank and smoothly tapering southern (down-ice) flank in combination with the orientation of the long axis parallel to the assumed direction of the Weichselian ice flow can be seen as indicators for the classification of the Klints Bank as an extraordinary large submarine drumlin. We therefore propose the denomination of the formation as "Klints Drumlin".

The Klints Drumlin consists of glaciogenic deposits without uniform stratification or deformation patterns and a seismic velocity of about $2000 \mathrm{~m} / \mathrm{s}$. Local sub-parallel reflection patches indicate an autochthonous sediment accumulation of the Klints Bank in contrast to the rather seismically transparent moraines in Fig. 9 a and b. Thrust faults and collapse structures at the flanks suggest that the feature was in part formed or overprinted during deglaciation, where the upper parts of the structure were exposed above the ice flow. According to the classification scheme developed by Stokes et al. (2011) in their Fig. 3, a "combined composition" is likely. The structure is neither homogenous nor conformable or unconformable; hence, we suggest a structural classification of "irregular", with subsequent, widespread deformation.

Phase-reversed events within and at the base of the Quaternary unit provide a strong indication of the presence of fluids (thermogenic hydrocarbons). The reservoir rock is assumed to be located within the Palaeozoic units at the eastern Baltic Basin, e.g. the mature Silurian oil reservoirs at western Lithuania.

Acknowledgements We thank Sven Winter, master Oliver Secci and the ALKOR crew for their great technical support during the cruise. The cruise was financially supported by the City of Hamburg (Behörde für Wissenschaft, Forschung und Gleichstellung). We further thank the fellow members of our working group at the University of Hamburg, including Elisabeth Seidel, Arne Warwel and Marie Blum, for their input and helpful discussions. IHS Markit and Schlumberger are thanked for providing the Kingdom ${ }^{\mathrm{TM}}$ and VISTA ${ }^{\circledR}$ Desktop Seismic Data Processing Software under Academic User Licence Agreements.

Code availability Not applicable.

Funding Open Access funding enabled and organized by Projekt DEAL. The cruise AL502 was financially supported by the City of Hamburg (Behörde für Wissenschaft, Forschung und Gleichstellung). This study was carried out under the umbrella of project HU698/24 of German Research Foundation DFG. IHS Markit and Schlumberger provided the Kingdom $^{\mathrm{TM}}$ and VISTA ${ }^{\circledR}$ Desktop Seismic Data Processing Software under Academic User Licence Agreements.

Data availability Data can be provided by Christian Hübscher (University of Hamburg, christian.huebscher@uni-hamburg.de) upon request.

\section{Compliance with ethical standards}

Conflict of interest The authors declare that they have no conflict of interest.

Open Access This article is licensed under a Creative Commons Attribution 4.0 International License, which permits use, sharing, adaptation, distribution and reproduction in any medium or format, as long as you give appropriate credit to the original author(s) and the source, provide a link to the Creative Commons licence, and indicate if changes were made. The images or other third party material in this article are included in the article's Creative Commons licence, unless indicated otherwise in a credit line to the material. If material is not included in the article's Creative Commons licence and your intended use is not permitted by statutory regulation or exceeds the permitted use, you will need to obtain permission directly from the copyright holder. To view a copy of this licence, visit http://creativecommons.org/licenses/by/4.0/. 


\section{References}

Al Hseinat M, Hübscher C (2017) Late Cretaceous to recent tectonic evolution of the North German Basin and the transition zone to the Baltic Shield/southwest Baltic Sea. Tectonophysics 708:28-55

Andrén T, Björck S, Andrén E, Conley D, Zillén L, Anjar J (2011) The development of the Baltic Sea Basin during the last $130 \mathrm{ka}$. In: Harff J, Björck S, Hoth P (eds) The Baltic Sea Basin (2011). Springer, Berlin Heidelberg, pp 13-51

Bjerkéus M, Eriksson M (2001) Late Silurian reef development in the Baltic Sea. GFF 123(3):169-179

Brangulis, A. P., Kanev, S. V., Margulis, L. S., Pomerantseva, R. A. (1993). Geology and hydrocarbon prospects of the Paleozoic in the Baltic region. In Geological Society, London, Petroleum Geology Conference series (Vol. 4, No. 1, pp. 651-656). Geological Society of London

Calner M, Jeppsson L, Munnecke A (2004) The Silurian of Gotlandpart I: review of the stratigraphic framework, event stratigraphy, and stable carbon and oxygen isotope development. Erlanger geologische Abhandlungen, Sonderband 5:113-131

Clark CD (2010) Emergent drumlins and their clones: from till dilatancy to flow instabilities. J Glaciol 56(200):1011-1025

Clark CD, Hughes AL, Greenwood SL, Spagnolo M, Ng FS (2009) Size and shape characteristics of drumlins, derived from a large sample, and associated scaling laws. Quat Sci Rev 28(7-8):677-692

De Vos W, Feldrappe H, Pharaoh TC, Smith NJP, Vejbak OV, Verniers J, Nawrocki J, Poprawa P, Bełka Z (2010) Pre-Devonian. In: Doornenbal JC, Stevenson AG (eds) Petroleum geological atlas of the Southern Permian Basin Area. EAGE Publications b.v. (Houten), pp 59-69

Dobrova H, Kolly E, Schmitz U (2003) E\&P ventures in the EasternCentral Europe transformation states after 1989-a review of expectations and results. Oil Gas European Magazine 29(4):172-212

Dowdeswell, J. A., Canals, M., Jakobsson, M., Todd, B. J., Dowdeswell, E. K., \& Hogan, K. A. (2016). Introduction: an atlas of submarine glacial landforms. In: Dowdeswell, J. A., Canals, M., Jakobsson, M., Todd, B. J., Dowdeswell, E. K., \& Hogan, K. (Eds.). (2016). Atlas of submarine glacial landforms: modern, Quaternary and ancient. Geological Society of London, Memoirs, 46(1), 3-14

Ehlers J, Grube A, Stephan HJ, Wansa S (2011) Pleistocene glaciations of North Germany - new results. In: Developments in quaternary sciences, vol 15. Elsevier, Amsterdam, pp 149-162

EMODnet Bathymetry Consortium (2018) EMODnet Digital Bathymetry (DTM)

Flodén T, Bjerkéus M, Tuuling I, Eriksson M (2001) A silurian reefal succession in the Gotland area, Baltic Sea. GFF 123(3):137-152

Fowler, A. C. (2009). Instability modelling of drumlin formation incorporating lee-side cavity growth. Proceedings of the Royal Society A: Mathematical, Physical and Engineering Sciences, 465(2109), 2681-2702

Fowler, A. (2011). Mathematical geoscience (Vol. 36). Springer Science \& Business Media. Amsterdam

Freimanis A, Margulis L, Brangulis A, Kanev S, Pomerantseva R (1993) Geology and hydrocarbon prospects of Latvia. Oil Gas J;(United States) 91(49)

Gelumbauskaite L (1995) Bottom relief and genesis of the Gotland depression. Baltica 9:65-75

Gerok D, Kaminskas D, Gibbard P (2017) Seismic velocity anomalies in the infilling of tunnel valleys: influence on the interpretation of seismic data. An example from western Lithuania. GFF 139(4): 276-288

Greenwood, S. L., Jakobsson, M., Hell, B., \& Öiås, H. (2016). Esker systems in the Gulf of Bothnia. In: Dowdeswell, J. A., Canals, M., Jakobsson, M., Todd, B. J., Dowdeswell, E. K., \& Hogan, K. (Eds.).
Atlas of submarine glacial landforms: modern, Quaternary and ancient. Geological Society of London, Memoirs, 46(1), 209-210

Greenwood SL, Clason CC, Nyberg J, Jakobsson M, Holmlund P (2017) The Bothnian Sea ice stream: early Holocene retreat dynamics of the south-central Fennoscandian Ice Sheet. Boreas 46(2):346-362

Hall A, van Boeckel M (2020) Origin of the Baltic Sea basin by Pleistocene glacial erosion. GFF 142(3):237-252

Hättestrand C (1998) The glacial geomorphology of central and northern Sweden. Sveriges Geologiska Undersökning, Uppsala

Hättestrand C, Götz S, Näslund JO, Fabel D, Stroeven AP (2004) Drumlin formation time: evidence from northern and central Sweden. Geografiska Annaler: Series A, Physical Geography 86(2):155-167

Heikkinen O, Tikkanen M (1989) Drumlins and flutings in Finland: their relationships to ice movement and to each other. Sediment Geol 62(2-4):349-355

Hooke RL, Medford A (2013) Are drumlins a product of a thermomechanical instability? Quat Res 79(3):458-464

Hübscher C, Gohl K (2016) Reflection/refraction seismology. In: Encyclopedia of earth sciences series. Springer, Berlin, pp 721-731

Hübscher C, Preine J, Broichgans N, Hildebrandt M, Huntenburg J, Hofmann A, Kurbjeweit O, Pelaez J, Schäfer S, Schütt S, Pan Y, Winter S, Ziegler H (2020) Seepraktikum Geophysik, Cruise No. AL526, 20.08.-03.09.2019, Kiel (Germany) - Kiel (Germany), Gutachterpanel Forschungsschiffe. Bonn. https://doi.org/10.2312/ cr al526

Hughes AL, Gyllencreutz R, Lohne ØS, Mangerud J, Svendsen JI (2016) The last Eurasian ice sheets-a chronological database and time-slice reconstruction, DATED-1. Boreas 45(1):1-45

Jakobsen PR (2012) Rock-cored drumlins on Bornholm, Denmark. Geological Survey of Denmark and Greenland (GEUS) Bulletin 26:17-20

Jakobsson, M., Greenwood, S. L., Hell, B., \& Öiås, H. (2016). Drumlins in the Gulf of Bothnia. In: Dowdeswell, J. A., Canals, M., Jakobsson, M., Todd, B. J., Dowdeswell, E. K., \& Hogan, K. (Eds.). Atlas of submarine glacial landforms: modern, Quaternary and ancient. Geological Society of London, Memoirs, 46(1), 197198

Johansson S, Sundius NG, Westerg rd AH (1943) Beskrivning till kartbladet Lidköping. Kungl boktryckeriet, PA Norstedt \& söner (in Swedish)

Jørgensen F, Piotrowski JA (2003) Signature of the Baltic ice stream on Funen Island, Denmark during the Weichselian glaciation. Boreas 32(1):242-255

Jørgensen F, Lykke-Andersen H, Sandersen PB, Auken E, Nørmark E (2003) Geophysical investigations of buried Quaternary valleys in Denmark: an integrated application of transient electromagnetic soundings, reflection seismic surveys and exploratory drillings. $\mathrm{J}$ Appl Geophys 53(4):215-228

Kanev S, Margulis L, Bojesen-Koefoed JA, Weil WA, Merta H, Zdanaviciute O (1994) Oils and hydrocarbon source rocks of the Baltic syneclise. Oil Gas J;(United States) 92(28)

King EC, Woodward J, Smith AM (2007) Seismic and radar observations of subglacial bed forms beneath the onset zone of Rutford Ice Stream, Antarctica. J Glaciol 53(183):665-672

Kristensen TB, Huuse M (2012) Multistage erosion and infill of buried Pleistocene tunnel valleys and associated seismic velocity effects. Geol Soc Lond, Spec Publ 368(1):159-172

Laier T (2003) Migration pattern of methane related to glacio-tectonic deformation of marine deposits in the Kattegat-Skagerrak area. Proceedings of ICGG7 (2003):44-46

McCann, T., Skompski, S., Poty, E., Dusar, M., Vozarova, A., Schneider, J., Wetzel, A., Krainer, K., Kornpihl, K., Schäfer, A., Krings, M., Oplustil, S., Tait, J. (2008). Permian. In McCann, T. (ed.), The geology of Central Europe, chap. 10, pp. 1-67. Geological Society, London 
Menzies J (1979) A review of the literature on the formation and location of drumlins. Earth Sci Rev 14(4):315-359

Menzies J, Hess DP, Rice JM, Wagner KG, Ravier E (2016) A case study in the New York Drumlin Field, an investigation using microsedimentology, resulting in the refinement of a theory of drumlin formation. Sediment Geol 338:84-96

Patton H, Hubbard A, Andreassen K, Winsborrow M, Stroeven AP (2016) The build-up, configuration, and dynamical sensitivity of the Eurasian ice-sheet complex to Late Weichselian climatic and oceanic forcing. Quat Sci Rev 153:97-121

Piotrowski JA (1997) Subglacial hydrology in north-western Germany during the last glaciation: groundwater flow, tunnel valleys and hydrological cycles. Quat Sci Rev 16(2):169-185

Piotrowski JA, Tulaczyk S (1999) Subglacial conditions under the last ice sheet in northwest Germany: ice-bed separation and enhanced basal sliding? Quat Sci Rev 18(6):737-751

Pletsch T, Appel J, Botor D, Clayton CJ, Duin EJT, Faber E, Gorecki W, Kombrink H, Kosakowski P, Kuper G, Kus J, Lutz R, Mathiesen A, Ostertag-Henning C, Papiernek B, Van Bergen F (2010) Petroleum generation and migration. In: Doornenbal JC, Stevenson AG (eds) Petroleum geological atlas of the Southern Permian Basin Area. EAGE Publications b.v. (Houten), pp 225-253

Rattas M, Piotrowski JA (2003) Influence of bedrock permeability and till grain size on the formation of the saadjärve drumlin field, Estonia, under an East-Baltic Weichselian Ice Stream. Boreas 32(1):167-177

Roskosch J, Winsemann J, Polom U, Brandes C, Tsukamoto S, Weitkamp A, Bartholomäus WA, Henningsen D, Frechen M (2015) Luminescence dating of ice-marginal deposits in northern Germany: evidence for repeated glaciations during the Middle Pleistocene (MIS 12 to MIS 6). Boreas 44:103-126

Saks T, Kalvans A, ZELCS V (2012) Subglacial bed deformation and dynamics of the Apriki glacial tongue, W Latvia. Boreas 41(1):124 140

Sivhed U, Erlström M, Bojesen-Koefoed JA, Löfgren A (2004) Upper Ordovician carbonate mounds on Gotland, central Baltic Sea: distribution, composition and reservoir characteristics. J Pet Geol 27(2): $115-140$

Šliaupa S (1999) Far-field stress transmission indications in early Palaeozoic structural evolution of the Baltic basin. Romanian Journal of Tectonics and Regional Geology 77(1):59

Šliaupa, S., \& Hoth, P. (2011). Geological evolution and resources of the Baltic Sea area from the Precambrian to the Quaternary. In: J. Harff, S. Björck, P. Hoth (Eds.), The Baltic Sea Basin (2011), pp. 13-51. Springer, Berlin Heidelberg

Šliaupa A, Gelumbauskaite Z, Straume J, Šliaupa S (1995) Neotectonic structure of eastern part of Baltic Sea and adjacent land area.
Technika Poszukiwań Geologicznych, Geosynoptika i Geotermia 3:63-65

Šliaupa S, Laškovas E, Lazauskienė J, Laškova L, Sidorov V (2004) The petroleum system of the Lithuanian offshore region. Zeitschrift für Angewandte Geology. Hannover:41-59

Šliaupa S, Fokin P, Lazauskiene J, Stephenson RA (2006) The VendianEarly Palaeozoic sedimentary basins of the East European Craton. Geol Soc Lond Mem 32(1):449-462

Smalley IJ, Unwin DJ (1968) The formation and shape of drumlins and their distribution and orientation in drumlin fields. J Glaciol 7(51): 377-390

Smith AM, Murray T, Nicholls KW, Makinson K, Ađalgeirsdóttir G, Behar AE, Vaughan DG (2007) Rapid erosion, drumlin formation, and changing hydrology beneath an Antarctic ice stream. Geology 35(2):127-130

Sopher D, Erlström M, Bell N, Juhlin C (2016) The structure and stratigraphy of the sedimentary succession in the swedish sector of the Baltic basin: new insights from vintage $2 \mathrm{~d}$ marine seismic data. Tectonophysics 676:90-111

Spagnolo M, Clark CD, Hughes AL, Dunlop P (2011) The topography of drumlins; assessing their long profile shape. Earth Surf Process Landf 36(6):790-804

Stokes CR, Spagnolo M, Clark CD (2011) The composition and internal structure of drumlins: complexity, commonality, and implications for a unifying theory of their formation. Earth Sci Rev 107(3-4): 398-422

Sviridov N, Emelyanov E (2000) Lithofacial complexes of quaternary deposits in the central and southeastern Baltic Sea. Lithol Miner Resour 35(3):211-231

Tuuling I, Flodén T (2011) Seismic stratigraphy, architecture and outcrop pattern of the Wenlock-Pridoli sequence offshore Saaremaa, Baltic Sea. Mar Geol 281(1-4):14-26

Wagner, R., (2011). Natural migration of liquid and gaseous subsurface hydrocarbons into bottom sediments and waters. In: S. Uścinowicz (Ed.), Geochemistry of Baltic Sea surface sediments (2011), pp. $125-145$

Woźniak PP, Czubla P (2015) The Late Weichselian glacial record in northern Poland: a new look at debris transport routes by the Fennoscandian Ice Sheet. Quat Int 386:3-17

Zdanaviciute O, Lazauskiene J (2004) Hydrocarbon migration and entrapment in the Baltic Syneclise. Org Geochem 35(2004):517-527

Zdanaviciute O, Lazauskiene J (2007) The petroleum potential of the Silurian succession in Lithuania. J Pet Geol 30(4):325-337

Publisher's note Springer Nature remains neutral with regard to jurisdictional claims in published maps and institutional affiliations. 